\title{
Serum Midkine Levels in Systemic Lupus Erythematosus
}

\author{
Blondina Marpaung ${ }^{*}$ Andi Raga Ginting, OK Moehad Sjah \\ Division of Rheumatology, Faculty of Medicine Universitas of Sumatera Utara, Medan, Indonesia
}

Citation: Marpaung B, Ginting AR, Sjah OKM. Serum Midkine Levels in Systemic Lupus Erythematosus. Open Access Maced J Med Sci. 2018 Aug 20; 6(8):1323-1327.

Keywords: Midkine; Systemic Lupus Erythematosus *Correspondence: Blondina Marpaung. Division of Rheumatology, Faculty of Medicine Universitas Sumatera Utara, Medan, Indonesia. E-mail. blondina@usu.ac.id

Received: 02-Jun-2018; Revised: 22-Jul-2018; Accepted: 27-Jul-2018; Online first: 14-Aug-2018

Copyright: $\odot 2018$ Blondina Marpaung, Andi Raga Ginting, OK Moehad Sjah. This is an open-access article distributed under the terms of the Creative Commons BY-NC 4.0).

Funding: This research did not receive any financia support.

Competing Interests: The authors have declared that no competing interests exist.

\begin{abstract}
BACKGROUND: Midkine (MK) induces inflammation and could inhibit inducible regulatory $\mathrm{T}$ cell differentiation. These reports suggest that MK may play a role in the pathogenesis of autoimmune disease including SLE, but data about MK in SLE patients was still limited, and the role of Midkine in SLE is largely unknown.

AIM: The purpose of this study was to compare serum level MK in SLE patients and control, also analysed the relationship between the serum MK level and disease activity in SLE.

METHODS: This cross-sectional study was conducted in Adam Malik Hospital from January-June 2017. Diagnosis of SLE was established according to the Systemic Lupus International Collaborating Clinics (SLICC) classification criteria, and disease activity was assessed using the Mexican Systemic lupus erythematosus disease activity index (MEX-SLEDAI). Subjects with evidence of malignancy and systemic disease (pulmonary, kidney, liver, metabolic disorder, etc.) were excluded. Data analysis was performed using SPSS 22nd version. P<
\end{abstract} 0.05 was considered statistically significant.

RESULTS: There were 90 subjects and divided into 2 groups: SLE patients group $(n=40)$ and healthy control groups $(n=50)$. Midkine levels were increased in the serum of SLE patients compared by health control. There was a significant difference in the median serum Midkine levels between SLE patients and healthy control $(P<$ 0.001). Elevated Midkine serum levels were a significant difference between active disease and remission $(P=$ $0.018)$.

CONCLUSION: Elevated Midkine serum level could be a marker of SLE disease activity and have a role in the pathogenesis of SLE.

\section{Introduction}

Systemic lupus erythematosus (SLE) is a common systemic inflammatory autoimmune disease. The immune response in SLE can cause chronic inflammation leading to irreversible damage to organ systems [1]. SLE is characterised by many immunologic abnormalities, such as polyclonal activation of circulating $B$ cells that generate a large number of autoreactive antibodies. SLE is also characterised by $\mathrm{T}$ lymphocyte abnormalities and immune complex (IC) deposition [2]. Cytokines that are derived from monocyte/macrophage play a key role in SLE pathogenesis. Cytokines collectively play key roles in the regulation of systemic inflammation, local tissue damage, and immunomodulation [3].
Midkine (MK) is a heparin-binding growth factor that was originally identified as the retinoic acid-response gene product. MK gene encodes it on chromosome 11 [4]. Midkine has a critical role in cell growth, survival, migration, angiogenesis, and carcinogenesis [5]. A higher midkine level in peripheral blood was associated with a poor outcome in patients with malignancies [6].

MK might modulate inflammatory responses [7]. MK induces inflammation via increasing leukocytes migration, induction of chemokine synthesis and preventing the development of regulatory $T$ cells [8]. Midkine could inhibit inducible regulatory $T$ cell differentiation by suppressing the development of tolerogenic dendritic cells [9]. It has been reported that MK level was elevated in the serum and synovial fluid of RA patients. These reports suggest that MK may play a role in the pathogenesis 
of RA [10]. Data about MK in SLE patients was still limited. Role of midkine in SLE is largely unknown. The purpose of the present study was to compare the serum level of MK in SLE patients and control, also analysed the relationship between the serum MK level and disease activity in SLE.

\section{Methods}

This study was a cross-sectional study on 40 consecutive SLE patients that were admitted to the Rheumatology Department and outpatient clinic of Adam Malik General Hospital and affiliated hospitals in Medan, Indonesia between January-June 2017. Diagnosis of SLE was established according to the Systemic Lupus International Collaborating Clinics (SLICC) classification criteria [11]. Subjects with evidence of malignancy and systemic disease (pulmonary, kidney, liver, metabolic disorder, etc.) were excluded.

Disease activity was assessed for all the patients using the Mexican Systemic lupus erythematosus disease activity index (MEX-SLEDAI). MEX-SLEDAI score has a score range of 0 to 32 , where the higher the score indicates, the more severe the activity of SLE disease. Active lupus is defined as the MEX-SLEDAl score > 5 [12]. Renal disorder in SLE patients according to SLICC classification criteria was proteinuria $(>0.5 \mathrm{~g} / 24 \mathrm{hr}$ ) or red blood cell casts [11]. Fifty age and sex-matched subjects were considered as a control group and were recruited from the relatives of the patients and healthcare providers in the hospital. The study was approved by the local ethics committee. All patients gave their informed consent before their inclusion in the study.

Serum MK was measured in all enrolled subjects using ELISA kit (Glory Science, USA). The assay is based on a double-antibody sandwich ELISA technique for the quantitative assay of human MK in samples. In this technique, MK binds to the monoclonal antibody-enzyme well which is precoated with human MK monoclonal antibody, making a solid phase antibody. Then MK antibody is added and combines with Streptavidin-Horseradish Peroxidase (HRP) to form an immune complex. Following incubation, MK is removed during a wash step and then substrates $A$ and $B$ are added to the wells and the colour of the liquid changes into blue. The coloured product is formed in proportion to the amount of MK present in the sample. The reaction is terminated by addition of sulphuric acid. The concentration of $\mathrm{MK}$ in the samples is then determined by comparing the (optical density) OD of the samples to the standard curve and values were reported as $\mathrm{pg} / \mathrm{mL}$.
Numerical data were expressed as mean \pm $\mathrm{SD}$, or median (interquartile range, IQR) if they were not in normal distribution. Data analysis was performed through univariate and bivariate analyses using the SPSS 22nd version (SPSS Inc., Chicago) with a $95 \%$ confidence interval. Bivariate analysis was performed using an Independent t-test and MannWhitney $U$ test with significance $p<0.05$.

\section{Results}

This study was followed by 90 subjects and divided into 2 groups: SLE patients group $(n=40)$ and Healthy control group $(n=50)$. There were $37(92.5 \%)$ female patients and $3(7.5 \%)$ male patients in group SLE. The mean age of the SLE group and healthy control group were $28.7(6.1)$ and 27.3 (5.8) years respectively. The median of disease duration in group SLE was 4.5 (0-9) years. 24 patient (57.5\%) in the SLE group had active disease (MEX-SLEDAI score > 5) and 19 patients (47.5\%) had renal disorder (Table 1).

Table 1: Basic and clinical characteristics of the subjects

\begin{tabular}{|c|c|c|}
\hline Characteristics & SLE patients $(n=40)$ & Healthy controls $(n=50)$ \\
\hline \multicolumn{3}{|l|}{ Gender $^{2}$} \\
\hline Female & 37 (92.5\%) & $46(92 \%)$ \\
\hline Male & $3(7.5 \%)$ & $4(8 \%)$ \\
\hline Age (years) ${ }^{\mathrm{D}}$ & $28.7(6.1)$ & $27.3(5.8)$ \\
\hline $\mathrm{BMI}(\mathrm{kg} / \mathrm{m} 2)^{\mathrm{b}}$ & $22.7(3.6)$ & $24.4(3.7)$ \\
\hline Disease duration (years) ${ }^{c}$ & $4.5(0-9)$ & NA \\
\hline Active Disease $^{a}$ & & NA \\
\hline Yes & $24(57.5 \%)$ & \\
\hline No & $16(42.5 \%)$ & \\
\hline Renal disorder ${ }^{a}$ & & NA \\
\hline Yes & $19(47.5 \%)$ & \\
\hline No & $21(52.5 \%)$ & \\
\hline
\end{tabular}

Midkine levels were increased in the serum of SLE patients compared by health control. There was a significant difference in the median serum Midkine levels between SLE patients and healthy control $(\mathrm{P}<$ $0.001)$. Patients SLE with active disease had midkine levels higher than remission group $(660.2 \pm 84.8)$ vs $(596.9 \pm 68.8) \mathrm{pg} / \mathrm{ml}$, there was a significant difference in serum Midkine levels between active disease and remission $(P=0.018)$ but there was no significant difference in serum Midkine levels in renal disorder group $(P=0.092)$ (Table 2$)$.

Table 2: Comparison of serum midkine between SLE patients, active disease and renal disorder groups

\begin{tabular}{lccl}
\hline Group & Number & Midkine Levels $(\mathrm{pg} / \mathrm{ml})$ & $\mathrm{p}$ \\
\hline SLE patients $^{\mathrm{a}}$ & 40 & $658(502-795)$ & $<0.001$ \\
Healthy controls & 50 & $510(370-750)$ & \\
Active Disease & & & \\
Yes & 24 & $660.2 \pm 84.8$ & 0.018 \\
$\quad$ No & 16 & $596.9 \pm 68.8$ & \\
Renal Disorder & & & \\
Yes & 19 & $658.4 \pm 75.2$ & 0.092 \\
No & 21 & $613.6 \pm 87.5$ & \\
\hline
\end{tabular}


SLE patients had serum Midkine levels higher than the control group; it can be seen in Figure 1, that median Midkine levels were $658(502-795) \mathrm{pg} / \mathrm{ml}$ in SLE patient group and $510(370-750) \mathrm{pg} / \mathrm{ml}$ in healthy control group.

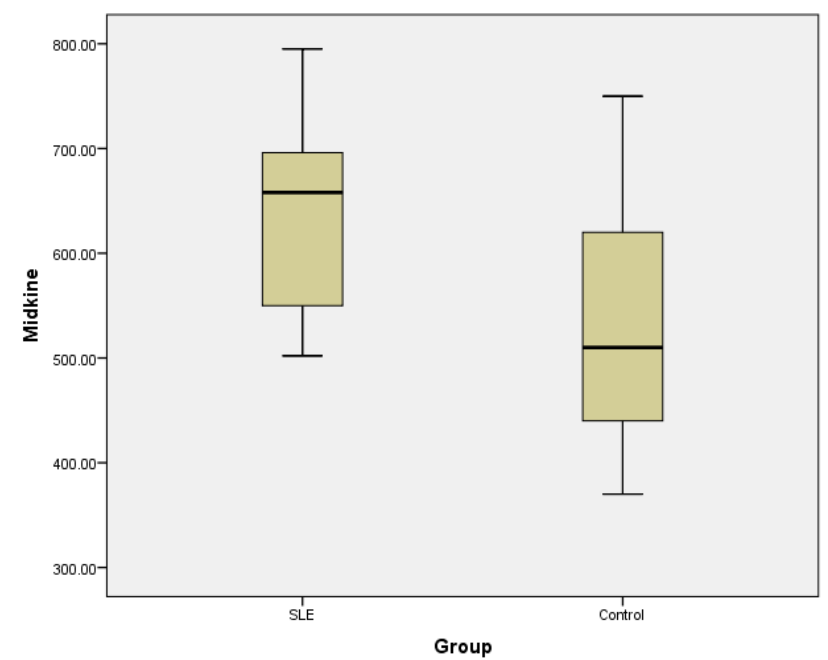

Figure 1: Boxplot diagram of Midkine level between SLE patients and controls

SLE patients, especially with active disease, had serum Midkine levels higher than remission group because of elevated levels of autoimmune inflammatory response (Figure 2).

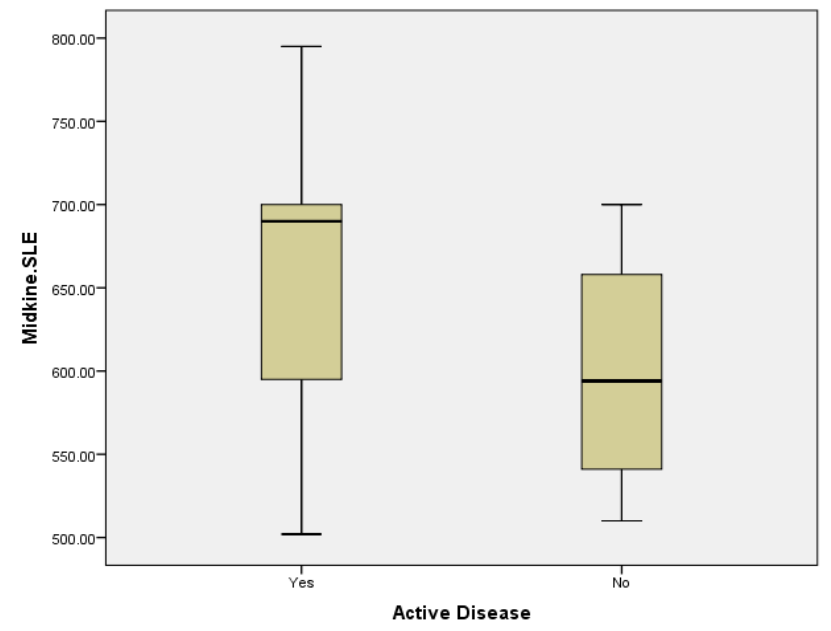

Figure 2: Boxplot diagram of Midkine level between Active disease and remission

Analysis result using the ROC curve obtained that cut off serum Midkine was $>569 \mathrm{pg} / \mathrm{ml}$. The area under the curve (AUC) was $75.1 \% \quad(p<0.001)$ with sensitivity and specificity of Midkine to predict diagnosis SLE were $70 \%$ and $60 \%$. Positive Prediction Value (PPV), Negative Prediction Value (NPV), Positive Likelihood ratio (PLR), and Negative Likelihood Ratio (NLR) were 58.3\%, 71.4\%, 1.75 and 0.5 respectively (Table 3 ).

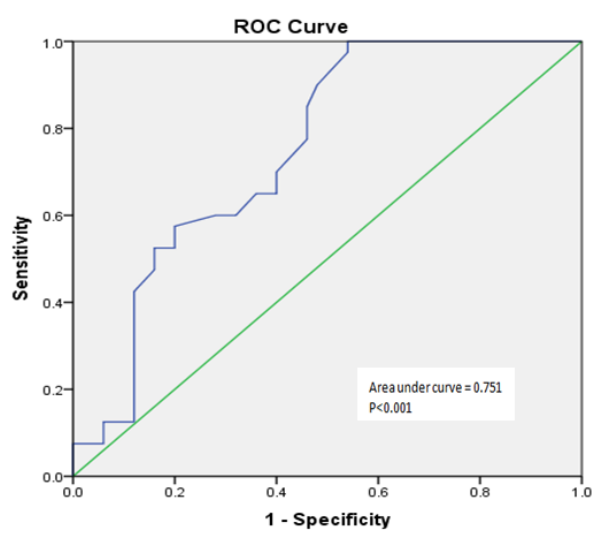

Figure 3: ROC curve of midkine level in the diagnosis of SLE

\section{Discussion}

SLE pathogenesis is closely related to the regulation of T lymphocytes. Regulatory $\mathrm{T}$ (Treg) cells are a subset of $\mathrm{CD} 4+\mathrm{T}$ cells that maintain selftolerance by suppressing autoreactive lymphocytes. Treg cells are required to restore the disturbed immune homeostasis in SLE, and the failure of Treg is related to the persistent inflammatory cytokine. Defects in Treg cells or a lack of Treg cells are contributed to SLE pathogenesis [13] [14].

Table 3: Accuracy of Midkine in the diagnosis of SLE

\begin{tabular}{rrccccccc}
\hline & Cut off & Sensitivity & Specificity & PPV & NPV & PLR & NLR & Accuracy \\
\hline Midkine & $>569$ & $70 \%$ & $60 \%$ & $58.3 \%$ & $71.4 \%$ & 1.75 & 0.5 & $75.1 \%$ \\
& $\mathrm{pg} / \mathrm{ml}$ & & & & & & & \\
\hline
\end{tabular}

The previous study explained that there was a negative correlation between Tregs and disease activity of SLE [15].

Midkine (MK) derived from CD4+ T cells has a role in promoting cell proliferation, cell survival, migration cells, and antiapoptotic activity in the nervous system, cancer and inflammation area. In inflammation process, MK induces cytokines and modulates migration of neutrophils and macrophages. MK activates T splenocytes, Th1 cell differentiation and has functioned as a negative immune modulator of Tregs in peripheral lymph nodes [16]. Inhibition of MK leads to an increase in Treg expansion and then suppresses the autoreactive Th1 cell population thus causing the reduced severity of the autoimmune disease [8].

This study examined Midkine serum level in SLE patients and healthy control. Median Midkine levels in this study were $658(502-795) \mathrm{pg} / \mathrm{ml}$ and 510 (370-750) $\mathrm{pg} / \mathrm{ml}$ in SLE patient group and healthy control group. Our result was comparable to a study conducted by $\mathrm{Wu} \mathrm{GC}$ et al., that reported median Midkine levels were 698.37 (516.09-767.07) $\mathrm{pg} / \mathrm{ml}$ 
and 628.22 (373.66-712.41) pg/ml in SLE patients and healthy control group. Our study result was consistent with Wu GC et al. that Midkine serum levels were significantly increased in SLE patient $(P<0.05)$ [17]. Elevated Midkine serum level also occurs in other autoimmune diseases such as rheumatoid arthritis and multiple sclerosis [10] [18].

Our result was consistent with $\mathrm{Wu}$ et al. that there was no significant difference in serum Midkine levels in SLE patients with and without the renal disorder $(P>0.05)$. But, there was a significant difference in serum Midkine levels between flare and remission in our result $(P=0.018)$ contrary to a previous study $(P>0.05)$ [17]. In Rheumatoid Arthritis (RA), Shindo et al. reported that MK level could be a biomarker of RA disease activity. There was correlation between serum $\mathrm{MK}$ and RA disease activity (DAS28-ESR) $(r=0.223, P=0.019)$ [10]. Same result in Crohn's Disease and Ulcerative Colitis that serum MK level was positive associated with Disease Activity Index [19] [20]. Midkine plays an important role in the pathogenesis of autoimmune diseases including SLE. Inhibiting Midkine can be useful to reduce the disease activity of autoimmune disease. In this study, cut off serum Midkine (> 569 $\mathrm{pg} / \mathrm{ml}$ ) had a moderately accuracy to predict SLE (AUC > 70\%) and a higher accuracy level than previous study [17].

This study has some limitations. MEXSLEDAl was used to assess the disease activity of SLE. MEX-SLEDAI was more simple but has a lower accuracy compared to the SLEDAI score. This study didn't compare the difference of Midkine levels with blood disorders group or neuropsychiatry disorder group of SLE patients. Further studies are required with larger samples to determine the role of Midkine as a predictive marker to diagnose SLE.

In conclusion, elevated Midkine serum level could be a marker of SLE disease activity and have a role in the pathogenesis of SLE.

\section{Acknowledgements}

We would like to express our gratitude to Prodia Education and Research Institute for assistance in Midkine testing, to Rumondang who has assisted the SLE patients in this study.

\section{References}

1. Buyon JP. Systemic Lupus Erythematosus. In: Klippel JH, Stone $\mathrm{JH}$, Crofford LeJ, White PH, eds. Primer on the Rheumatic Diseases. Springer, 2008:303-338. https://doi.org/10.1007/978-0-

\section{$\underline{387-68566-3 \quad 15}$}

2. Tahernia L, Namazi S, Rezaei N and Ziaee V. Cytokines in systemic lupus eryhtematosus: their role in pathogenesis of disease and possible therapeutic opportunities. Rheum Res. 2017; 2(1):1-9. https://doi.org/10.22631/rr.2017.69997.1010

3. Jacob N, Stohl W. Cytokine disturbances in systemic lupus erythematosus. Arthritis Res Ther. 2011; 13:228. https://doi.org/10.1186/ar3349 PMid:21745419 PMCid:PMC3239336

4. Ibusuki M, Fujimori H, Yamamoto Y, Ota K, Ueda M, Shinriki S, et al. Midkine in plasma as a novel breast cancer marker. Cancer Sci. 2009; 100(9):1735-1739. https://doi.org/10.1111/j.13497006.2009.01233.x PMid:19538527

5. Muramatsu T. Midkine and pleiotrophin: two related proteins involved in development, survival, inflammation and tumorigenesis. J Biochem. 2002; 132: 359-371.

https://doi.org/10.1093/oxfordjournals.jbchem.a003231 PMid:12204104

6. Hung YJ, Lin ZH, Cheng TI, Liang CT, Kuo TM and Kao KJ. Serum Midkine as a Prognostic Biomarker for Patients With Hepatocellular Carcinoma. Am J Clin Pathol. 2011; 136:594-603 https://doi.org/10.1309/AJCPWT70XOVXSVGE PMid:21917682

7. Weckbach LT, Muramatsu T, Walzog B. Midkine in inflammation. Sci World J. 2011; 11:2491-2505.

https://doi.org/10.1100/2011/517152 PMid:22235180

PMCid:PMC3253530

8. Wang J, Takeuchi H, Sonobe Y, Jin S, Mizuno T, Miyakawa S, et al. Inhibition of midkine alleviates experimental autoimmune encephalomyelitis through the expansion of regulatory $\mathrm{T}$ cell population. Proc Natl Acad Sci U S A. 2008; 105: 3915-3920. https://doi.org/10.1073/pnas.0709592105 PMid:18319343 PMCid:PMC2268842

9. Sonobe Y, Li H, Jin S, Kishida S, Kadomatsu K, Takeuchi H, et al. Midkine inhibits inducible regulatory $T$ cell differentiation by suppressing the development of tolerogenic dendritic cells. J Immunol. 2012; 188:2602-2611.

https://doi.org/10.4049/iimmunol.1102346 PMid:22323540

10. Shindo E, Nanki T, Kusunoki N, Shikano K, Kawazoe M, Sato $\mathrm{H}$, et al. The growth factor midkine may play a pathophysiological role in rheumatoid arthritis. Mod Rheumatol. 2016; 1:1-6

11. Petri M, Orbai AM, Alarcon GS, et al. Derivation and validation of the Systemic Lupus International Collaborating Clinics classification criteria for systemic lupus erythematosus. Arthritis Rheum. 2012;64:2677. https://doi.org/10.1002/art.34473 PMid:22553077 PMCid:PMC3409311

12. Khanna S, Pal H, Pandey RM, Handa R. The relationship between disease activity and quality of life in systemic lupus erythematosus. Rheumatology. 2004; 43(12):1536-40. https://doi.org/10.1093/rheumatology/keh376 PMid:15342925

13. Scheinecker $C$, Bonelli $M$ and Smolen JS. Pathogenetic aspects of systemic lupus erythematosus with an emphasis on regulatory T cells. J Autoimmun. 2010; 35: 269-275. https://doi.org/10.1016/i.jaut.2010.06.018 PMid:20638240

14. Ohi $\mathrm{K}$ and Tenbrock $\mathrm{K}$. Regulatory $\mathrm{T}$ cells in systemic lupus erythematosus. Eur J Immunol. 2015; 45(2):344-355. https://doi.org/10.1002/eji.201344280 PMid:25378177

15. Liu Z, Davidson A. Taming lupus-a new understanding of pathogenesis is leading to clinical advances. Nat Med. 2012; 18: 871-882. https://doi.org/10.1038/nm.2752 PMid:22674006 PMCid:PMC3607103

16. Masuda T, Maeda K, Sato W, et al. Growth factor midkine promotes nuclear factor of activated T cells-regulated T-cellactivation and Th1 cell differentiation in lupus nephritis. Am J Pathol. 2017; 184(4):740-751. https://doi.org/10.1016/i.ajpath.2016.12.006 PMid:28183532

17. Wu GC, Yuan H, Pan HF, Ye DQ. Elevated plasma midkine and pleiotrophin levels in patients with systemic lupus erythematosus. Oncotarget. 2017; 8(25): 40181-40189. https://doi.org/10.18632/oncotarget.13658 PMid:27903979 
PMCid:PMC5522313

18. Shaygannejad V, Montazeri S, Jamshidian A, et al. Correlation of midkine serum level with pro-and anti-inflamatory cytokines in multiple sclerosis. Iran J Immunol. 2014; 11:134-138.

PMid:24975970

19. Krzystek-Korpacka M, Neubauer K, Matusiewicz M. Clinical relevance of circulating midkine in ulcerative colitis. Clin Chem Lab
Med. 2009; 47:1085-1090. https://doi.org/10.1515/CCLM.2009.248 PMid:19728850

20. Krzystek-Korpacka M, Neubauer K, Matusiewicz M. Circulating midkine in Crohn's disease: clinical implications. Inflamm Bowel

Dis. 2010; 16:208-215. https://doi.org/10.1002/ibd.21011 PMid:19572374 